\title{
Synthesis of Metforminium Succinate by Melting. Crystal Structure, Thermal, Spectroscopic and Dissolution Properties
}

\author{
Eduardo Plata-Vargas, ${ }^{1}$ Cinthia de la Cruz-Hernández, ${ }^{1}$ Alejandro Dorazco-González, ${ }^{1, *}$ \\ Inés Fuentes-Noriega, ${ }^{2}$ David Morales-Morales ${ }^{3}$ and Juan Manuel Germán-Acacio ${ }^{4, *}$
}

1 Centro Conjunto de Investigación en Química Sustentable UAEM-UNAM, Instituto de Química, Universidad Nacional Autónoma de México, Carretera Toluca-Atlacomulco Km 14.5 C. P. 50200 Toluca, Estado de México, México.

2 Laboratorio de Biofarmacia, Departamento de Farmacia, Facultad de Química, UNAM.

3 Instituto de Química, Universidad Nacional Autónoma de México, Circuito Exterior, Ciudad Universitaria, México, CDMX, C.P. 04510, México.

4 Red de Apoyo a la Investigación, Instituto Nacional de Ciencias Médicas y Nutrición SZ-Universidad Nacional Autónoma de México (CIC-UNAM), México CDMX, C.P. 14000, México.

Corresponding author: jmga@cic.unam.mx

Received December 14 ${ }^{\text {th }}, 2016$; March 22 $2^{\text {nd }}, 2017$.

\begin{abstract}
The reaction by melt mixing at $220^{\circ} \mathrm{C}$ of the antihyperglycemic drug metformin hydrochloride $\mathbf{1}$ with dehydrated sodium succinate yields efficiently the organic salt $[\mathrm{MET}]_{2}[\mathrm{SUC}] 2\left(\mathrm{H}-\mathrm{MET}^{+}=\right.$ metforminium and $\mathrm{SUC}^{2-}=$ succinate). Solid state CPMAS NMR ${ }^{13} \mathrm{C}$ spectroscopy experiments, powder X-ray diffraction and FT-IR results support the formation of the pharmaceutical salt $\mathbf{2}$ in good yields. Besides, the charged-assisted hydrogen bonding interactions of type $\mathrm{N}-\mathrm{H}^{\cdots-} \mathrm{O}$ (carboxylate) were thoroughly analyzed by single crystal X-Ray diffraction techniques. Thus, the pharmaceutical salt 2 possesses considerable thermal differences when compared to the pure starting reagents. In addition, intrinsic dissolution rate experiments in buffered aqueous solutions at $\mathrm{pH}=6.8$ showed a sustained-release behavior of the drug in 2 with a constant value of $K_{\text {int }}=0.885 \mathrm{mg} / \mathrm{min} * \mathrm{~cm}^{2}$.

Keywords: Diabetes; Metformin; X-ray structures; ssCPMAS NMR

${ }^{13} \mathrm{C}$; Melting; Succinate; mechanochemistry; green chemistry.
\end{abstract}

\section{Introduction}

The design and preparation of salts or co-crystals of API's (active pharmaceutical ingredients) is a current trend in Crystal Engineering and pharmaceutical sciences. It is well known that physical chemical and biological properties of API's can be altered incorporating co-formers without having any covalent modification forming co-crystals [1]. Among these pharmaceutical co-crystals, there is a great interest in Metformin due to its global importance as an oral antidiabetic drug. Metformin is a biguanidine compound used for the treatment of type 2 diabetes mellitus (T2DM), in particular in overweigh and obese people. Metformin hydrochloride (MET. $\mathrm{HCl}) \mathbf{1}$ improves glucose tolerance in patients with $\mathrm{T} 2 \mathrm{DM}$, lowering plasma glucose levels [2] and glycated hemoglobin $\mathrm{HbA}_{1 \mathrm{c}}$. [3-5]

Despite these benefits 1 is associated with gastric disorders in patients with prolonged use due to the release of high concentration of chloride anion [6] and metformin freebase has low
Resumen. La reacción por fusión a $220^{\circ} \mathrm{C}$ del fármaco antihiperglucémico clorhidrato de metformina 1 con succinato de sodio deshidratado produce eficientemente la sal orgánica $[\mathrm{MET}]_{2}$ [SUC] $2\left(\mathrm{H}-\mathrm{MET}^{+}=\right.$ metforminio y $\mathrm{SUC}^{2-}=$ succinato). Los estudios espectroscópicos de RMN en estado sólido CPMAS ${ }^{13} \mathrm{C}$, difracción de rayos $\mathrm{X}$ de polvos $\mathrm{y}$ FT-IR, soportan la formación de la sal farmacéutica 2 con un buen rendimiento. Los patrones de las interacciones de enlace de hidrógeno asistido por carga $\mathrm{N}-\mathrm{H}^{\cdots} \mathrm{O}^{-}$(carboxilato) se analizaron minuciosamente mediante difracción de rayos $\mathrm{X}$ de monocristal. La sal farmacéutica 2 posee diferencias térmicas considerables en comparación con los reactivos de partida puros. Los experimentos de velocidad de disolución intrínseca en soluciones acuosas tamponadas a $\mathrm{pH}=6,8$ mostraron un comportamiento de liberación de fármaco con un valor constante de $K_{\text {int }}=0.885 \mathrm{mg} / \mathrm{min} * \mathrm{~cm}^{2}$.

Palabras clave: Diabetes; metformina; estructuras de rayos X; CPMAS ${ }^{13} \mathrm{C}$ RMN; fusión; succinato; mecanoquímica; química verde.

intestinal absorption (approximately 50\% to 60\%) [2]. Fact that has encouraged the scientific community to design and prepare new Metformin pharmaceutical based formulations [6].

In this context, we explored the preparation of $[\mathrm{MET}]_{2}$ [SUC] $\mathbf{2}$ by melt mixing of $\mathbf{1}$ in the presence of dehydrated $\mathrm{Na}_{2}[\mathrm{SUC}]_{2}$. In this case, we are interested in replacing the anion $\mathrm{Cl}^{-}$based on the concepts of the crystal engineering and using melting procedures [7], exploiting the well-known ability of the carboxylate and guanidinium groups to form charged-assisted hydrogen bonding in solid state (Scheme 1) [8].

According to Nanubolu et. al. [8] ten metforminium $\left(\mathrm{H}_{-\mathrm{MET}^{+}}\right)$salts with different anions have been deposited at the Cambridge Structural Database CSD [9]. Five of them including the monocation $\mathrm{H}_{-} \mathrm{MET}^{+}$(two hydrochloride polymorphs, bromide, nitrate and one acetate salts) and five more having the metformin dication $\left(\mathrm{H}_{2}-\mathrm{MET}^{2+}\right.$, oxalate, sulfate, perchlorate, squarate and calixiarenesulfonate salts). Nanubolu also discusses the formation of two polymorphs of the salt 
$[\mathrm{MET}]_{2}[\mathrm{EMB}]\left(\mathrm{EMB}^{2-}=\right.$ embonate $)[8]$. In addition, the formation of the salt [MET][SAL] $\left(\mathrm{SAL}^{-}=\right.$salicylate) $[10]$, and the drug-drug salt [MET][GLI] containing two antidiabetic agents in the same solid phase (GLI, glicazide is a drug of the sulfonylurea-type) have been recently reported [11].
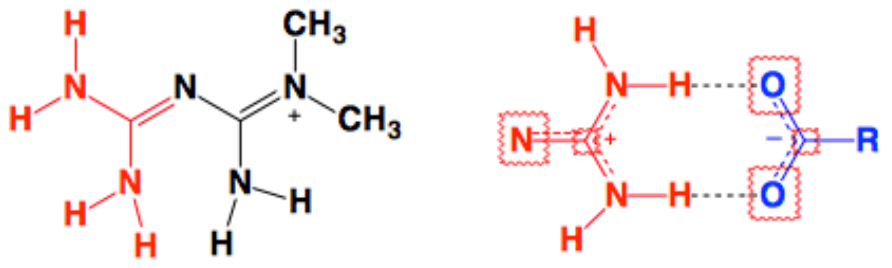

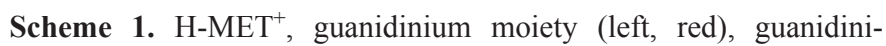
um(red)...carboxylate(blue) dimer motif assisted by charge (right).

Some patents related with formation of organic salts, including at least one $\mathrm{H}_{-} \mathrm{MET}^{+}$and one carboxylate group are: (a) US $006031004 \mathrm{~A}$, salts of $[\mathrm{MET}]^{2}[\mathrm{SUC}]$ and $[\mathrm{MET}]_{2}[\mathrm{FUM}]$ $\left(\mathrm{FUM}^{2-}=\right.$ fumarate $)$ only preparation by dissolution processes and thermal behavior [12a-b]. (b) WO 2009/038396 A2, which describes the formation of a family of salts of $\mathrm{H}_{-\mathrm{MET}^{+}}$with a series of carboxylates [malate $\left(\mathrm{MAL}^{2-}\right)$, malonate $\left(\mathrm{MLN}^{2-}\right)$, glutarate $\left(\mathrm{GLU}^{2-}\right)$ and adipate $\left.\left(\mathrm{ADI}^{2-}\right)\right][12 \mathrm{c}-\mathrm{d}]$. (c) WO 2008/093984 A1, salt of [MET][ACE] $\left(\mathrm{ACE}^{-}=\right.$acetate) [12e]. (d) US 2014/0249221 A1, describes the formation of salts con-

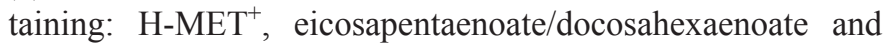
aspartate or glutamate [12f]. (e) WO 2009/085198 A2, salt of $\mathrm{H}^{-\mathrm{MET}^{+}}$with $\alpha$-lipoate, combined with different anti-obesity agents [12g]. (h) WO $2009144527 \mathrm{~A} 1$, salt of [MET][GLY] (GLY- = glycinate) [12h] and (i) KR $2011123881 \mathrm{~A}$, salt of $[\mathrm{MET}]_{2}[\mathrm{SUC}][12 \mathrm{i}]$.

The salt of $\mathbf{2}$ has been extensively studied for its biological effects; however, its crystalline structure and solid state NMR spectroscopic characterization has not been reported. Thus, the results obtained from the synthesis by melting of the pharmaceutical salt 2 including its X-Ray crystal structure, spectroscopic studies and physical chemical properties are summarized below.

\section{Experimental}

\subsection{Materials and Methods}

All reagents for synthesis and analysis were of analytical grade and were used as received without further purification. MET $\cdot \mathrm{H}-$ $\mathrm{Cl} 1$ was purchased from Tokyo Chemical Industry Co. All other reagents were obtained from Sigma Aldrich Chemical Co. and the solvents were purchased from JT Baker. The disodium succinate salt was obtained by vigorous grinding (agate mortar and pestle) of succinic acid $\left(\mathrm{H}_{2} \mathrm{SUC}\right)$ in the presence of $\mathrm{NaOH}$ (1:2 molar ratio). The reaction is exothermic and water is produced during the process affording a white paste. This paste was further grinded for $10 \mathrm{~min}$. affording a white powder that were desiccated in an oven at $110^{\circ} \mathrm{C}$ for $4 \mathrm{~h}$.

$\mathrm{Na}_{2}$ [SUC]. IR-ATR (cm $\left.{ }^{-1}\right) .3361(\mathrm{w}), 3250(\mathrm{w}), 1669(\mathrm{~m})$, $1544(\mathrm{~s}), 1401(\mathrm{~s}), 1237(\mathrm{w}), 1157(\mathrm{w}), 816(\mathrm{~m}), 729(\mathrm{~s}), 663$ (s), 552 (s). ssCPMAS ${ }^{13} \mathrm{C}$ NMR(ppm). $\mathrm{Na}+-\mathrm{OOC}-* \mathrm{CH}_{2}-$ ${ }^{*} \mathrm{CH}_{2}-\mathrm{COO}-\mathrm{Na}+(\delta=34.74), \mathrm{Na}+-\mathrm{OOC}^{*}-\mathrm{CH}_{2}-\mathrm{CH}_{2}-\mathrm{C} * \mathrm{OO}-$ $\mathrm{Na}+(\delta=181.60)$.

\subsection{Synthesis by Melt Mixing}

MET $\cdot \mathrm{HCl}, 1$ (165.6 mg, $1.0 \mathrm{mmol})$ and dehydrated disodium succinate $\left(81 \mathrm{mg}, 0.5 \mathrm{mmol}\right.$ ) were melted at $220^{\circ} \mathrm{C}$ for $5 \mathrm{~min}$. and the resulting white powder was ground for $10 \mathrm{~min}$ at room temperature. Suitable single crystals of $\mathbf{2}$ for X-Ray diffraction were obtained by slow evaporation of saturated methanolic of $\mathbf{1}$ at room temperature. Figures of the crystalline structures of $\mathbf{2}$ were generated by the programs X-Seed [13], and Olex 2 [14].

\subsection{Spectroscopic characterization and thermal analyses}

Infrared spectra were recorded on a Bruker Tensor 27 ATR spectrophotometer and measured in the range of 4000-400 $\mathrm{cm}^{-1}$. Melting points of $\mathbf{1}$ and $\mathbf{2}$ were determined using a Fisher Johns apparatus and are reported without correction. Thermogravimetric analysis and differential scanning calorimetry (TGA-DSC) were performed on a NETZSCH STA 449F3 apparatus. The analyses were performed at a heating rate of $10^{\circ} \mathrm{C} /$ min within the temperature range of $30-400{ }^{\circ} \mathrm{C}$ using a current of nitrogen as inert gas purge $(10 \mathrm{~mL} / \mathrm{min})$. Solid-state ${ }^{13} \mathrm{C}$ NMR spectra of $\mathbf{1}$ and $\mathbf{2}$ were recorded at $298 \mathrm{~K}$ on a Varian 300 spectrometer operating at Larmor frequencies of 75.4, 79.3. The ${ }^{13} \mathrm{C}$ experiments were performed with cross-polarization (CP), high power decoupling, and magic angle spinning (MAS) and contact time $\mathrm{t}_{\mathrm{CP}} 1500$, using a Bruker double-bearing probe head, spinning speed $4.5 \mathrm{KHz}$.

\subsection{Crystallographic investigations}

Powder $\mathrm{X}$ ray diffraction experiments were performed in a Bruker D500 diffractometer operated at $40 \mathrm{kV}$ and $35 \mathrm{~mA}$ with $\mathrm{Cu} \mathrm{K \alpha}$ radiation (1.5406 $\AA$ ), radius of $217 \mathrm{~mm}$, divergence slit $0.6 \mathrm{~mm}$ and anti-scattering slit $0.1 \mathrm{~mm}$, with soller of $2.6^{\circ}$, graphite monocromator and scintillation detector. The range of measurement was from $5-75^{\circ}$.

The relevant details of $\mathbf{2}$, data collection and structure refinement can be found in Fig. 2. Data collection for $\mathbf{2}$ was performed at $298{ }^{\circ} \mathrm{C}$ using MoK $\alpha$ radiation on a Bruker APEX II CCD instrument. Semi-empirical absorption correction was applied to all data sets [15]. Structure solutions, refinements, and geometrical calculations were carried out by SHELXTL [16]. The structure was refined using full-matrix least squares methods on F2 with all non-H atoms anisotropically defined. The hydrogen atoms were placed in calculated positions using the "riding model" with Uiso $=$ aUeq (where a is 1.5 for $-\mathrm{CH}_{3}$ and $-\mathrm{OH}$ moieties and 1.2 for others). 


\section{Results and Discussion}

\subsection{DSC-TGA studies}

Evidence for the formation of the salt $\mathbf{2}$ was initially obtained from the DSC and TGA studies. DSC experiments were used to follow the progress of the reaction. The DSC thermograms of 1 and $\mathbf{2}$ are shown in Fig. 1. The peak of $\mathbf{2}$ at $243{ }^{\circ} \mathrm{C}$ does not correspond to the melting point of either of the starting materials [17-18], indicating the formation of a new solid phase. The relevant thermal data are collected in Table 1.

Thus the results obtained for $\mathbf{2}$ clearly show the formation of a new salt with higher thermal stability, properly fitting with those reported for other co-crystals/salts containing carboxylic acid functional moieties [7e]. The DSC profile of $\mathbf{2}$ exhibits one thermal event at $210-250{ }^{\circ} \mathrm{C}$ due to the melting of the salt. The
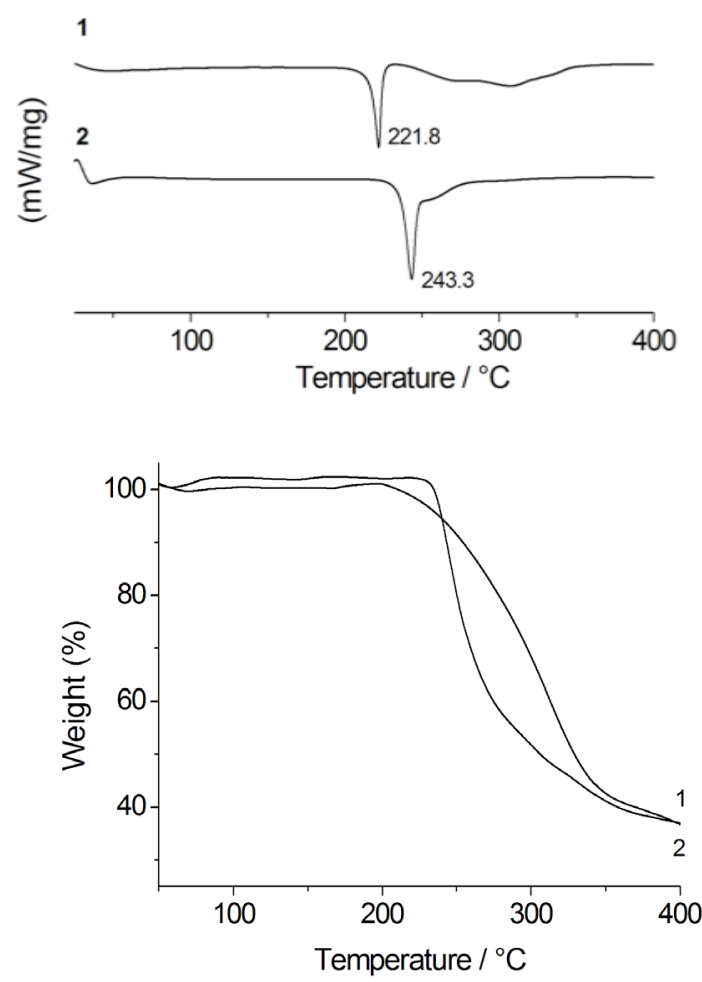

Fig. 1. DSC thermograms of $\mathbf{1}$ and $\mathbf{2}$. The peaks in the figure are related to the first thermal event (left). TGA profiles of $\mathbf{1}$ and $\mathbf{2}$ (right). second process, in the range $250-290{ }^{\circ} \mathrm{C}$, can be attributed to the decomposition of two H-MET ${ }^{+}$cations followed by the decomposition of $\mathrm{SUC}^{2-}$. This fact is supported by simultaneous TGA measurements.

\subsection{Crystal structure}

The salt $\mathbf{2}$ crystallizes in the monoclinic $\mathrm{P} 2_{1} / \mathrm{c}$ space group (Fig. 2). The asymmetric unit includes one $\mathrm{H}_{-\mathrm{MET}^{+} \text {and half mole- }}$ cule of $\mathrm{SUC}^{2-}$, in agreement with the stoichiometry ratio found by DSC-TG analysis (Fig. 2).

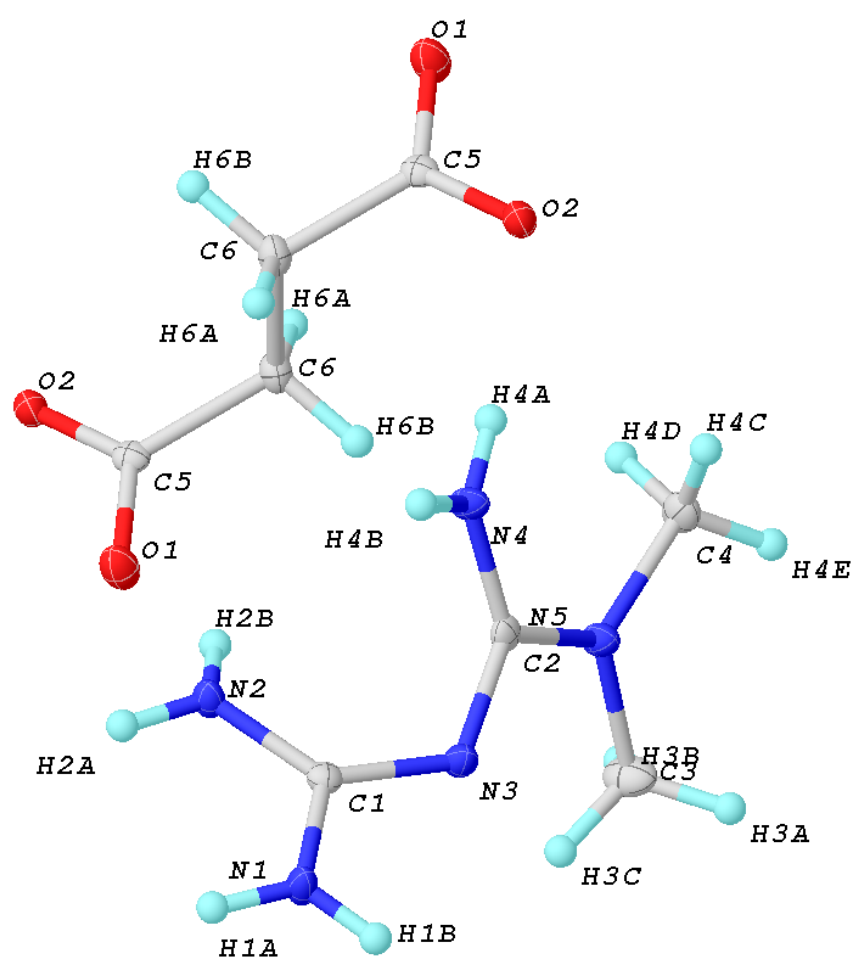

Fig. 2. Unit cell of 2. Ellipsoids were drawn at 50\% of probability. Crystal data for (2): formula $\mathrm{C}_{6} \mathrm{H}_{14} \mathrm{~N}_{5} \mathrm{O}_{2}$, F.W. 188.22, Monoclinic, $\mathrm{P} 2{ }_{1} / \mathrm{n}$, a 9.5551(3) $\AA, \mathrm{b} 8.8279(3) \AA$ and c 10.8487(3) $\AA, \alpha 90^{\circ}, \beta$ 92.4900(10) ${ }^{\circ}$ and $\gamma 90^{\circ}, \mathrm{V}$ 897.03(5) $\AA^{3}, \mathrm{Z}=4$, pcalc $1.367\left(\mathrm{~g} \mathrm{~cm}^{-3}\right)$, $\mu(\mathrm{MoK} \alpha) 0.105 \mathrm{~mm}^{-1}, \mathrm{~F}(000) 404$, crystal size $0.374 \AA \mathrm{x} 0.22 \AA \mathrm{x} 0.18$ $\AA \mathrm{mm}^{3}, 2 \Phi$ range $5.562-50.576^{\circ}, \mathrm{T} 298(2) \mathrm{K}$, Reflections collected 7485 , Independent reflections 1657 [Rint $=0.0282, \mathrm{R} \sigma=0.0211]$, data/ restrains/parameters 1657 / 6 / 139, GOF on $\mathrm{F}^{2} 1.073$, Final R indexes $[\mathrm{I}>=2 \sigma(\mathrm{I})] \mathrm{R} 1=0.0345, \mathrm{wR} 2=0.0909$, Final $\mathrm{R}$ indexes [all data] $\mathrm{R} 1$ $=0.0408, \mathrm{wR} 2=0.0971$, Largest diff. peak $/$ hole $/ \mathrm{e} \AA^{-3} 0.29 /-0.21$.

Table 1. Relevant data from DSC-TG analyses of $\mathbf{1}$ and $\mathbf{2}$.

\begin{tabular}{|c|c|c|c|c|}
\hline Salt $^{b}$ & $\begin{array}{c}\text { m.p. } \\
\text { exp/calcd }\left({ }^{\circ} \mathrm{C}\right)\end{array}$ & $\begin{array}{c}\text { peak } \\
\text { temp }\left({ }^{\circ} \mathrm{C}\right)^{\mathrm{a}}\end{array}$ & $\begin{array}{c}\Delta \mathbf{H}_{\text {fus }} \\
\mathrm{J} / \mathrm{g}^{\mathrm{a}}\end{array}$ & $\begin{array}{c}\% \text { weight loss } \\
\text { exp/calcd }\end{array}$ \\
\hline 1 & $219-221 / 216-218$ & 221.8 & 229.2 & - \\
\hline
\end{tabular}

${ }^{a}$ Peak temperature and $\Delta$ Hfus of $\mathbf{1}$ and $\mathbf{2}$, is regarding to the first thermal event observed in DSC experiments.

${ }^{\mathrm{b}}$ Crushed single crystals were employed.

$\mathrm{T}_{\text {decomp }}$ of pure disodium succinate, $470{ }^{\circ} \mathrm{C} .{ }^{18}$ 
So far, there are three tautomeric forms reported for the cation $\mathrm{H}_{-\mathrm{MET}^{+}}$in the solid state (Scheme 2). In our case, the H-MET ${ }^{+}$in $\mathbf{2}$ corresponds to tautomer (c). Thus, the crystal structure shows the C-N bond distances in $\mathrm{H}_{-} \mathrm{MET}^{+}$to be in the range of 1.330(2)-1.453(2) $\AA$, these values are intermediate between a single and a triple bond [19-20], indicating a delocalized $\pi$ electron system across the molecule. The H-MET ${ }^{+}$cation is non-planar with a torsion angle C3-N2-C4-N5 of $144.55^{\circ}$.

The $\mathrm{H}-M E T^{+}$is linked to $\mathrm{SUC}^{2-}$ via different hydrogen bonds with different motifs (Fig. 3). Table 2 contains the geometric parameters for selected hydrogen bonds. The most relevant motifs identified (based on graph set theory [21]) are guanidinium $\cdots$ guanidinium [dimer $\mathrm{R}_{2}^{2}(8)$ motif I], charged-assisted hydrogen bonds guanidinium $\cdots$ carboxylate [dimer $\mathrm{R}_{2}^{2}(8)$ motif II] and N-H $\cdots \mathrm{O}^{-}$(carboxylate) [tetramer $\mathrm{R}_{4}^{2}(8)$ motif III] (Fig. 3, Table 2).

Motifs I-III produce infinite layers along the $a$-axis (Fig. 3). In this case, motif I is perfectly aligned between the planes N2-C3-N3-3HA and N2-C3-N3-3HA. However, motif II exhibits a deviation of $25.93^{\circ}$ between the plane O2-C1-O1 (carboxylate) and the plane H1B-N1-C3-N3-H3B. A comparison of this value with similar structures deposited at CSD $\left(6.5^{\circ}\right.$ aminoguanidinium hydrogensuccinate-GOLXUB [22], $12.45^{\circ}$ biguanidium hydrogen succinate-PUNPUK [23], $9.27^{\circ}$ guanidinium hydrogen succinate-SEWXAU [24], 6.46 2-phenylbiguanidinium hydrogen succinate methanol solvate-WADTEC [25]) reveal a significant deviation of motif II in $\mathbf{2}$. This probably being due to the juxtaposition of motif II with motif III in the crystal lattice (Fig. 3). Thus constraining the spatial approaching of the carboxylate and guanidinium moieties; moreover, in motif III the tetramer $\mathrm{R}_{4}^{2}(8)$ is completely planar.

Other identifiable motifs in the structure, such as $\mathrm{N}-\mathrm{H}^{\cdots} \mathrm{O}^{-}$ (carboxylate) $\left[\mathrm{R}_{4}^{2}(12)\right.$ formed by N3-H3B $\cdots \mathrm{O} 12.051(13) \AA$, N4-H4A...O1 2.001(12) $\AA$ and N4-H4B ‥O1 2.154(13) $\AA$ ] and $\mathrm{N}-\mathrm{H}^{\cdots} \mathrm{O}^{-}$(carboxylate) $\left[\mathrm{R}_{2}^{2}(13)\right.$ formed by N1-H1A $\cdots \mathrm{O} 2$ $2.045(15) \AA$ and N4-H4A $\cdots$ O1 2.001(12) $\AA$ ] allow the extend of the $3 \mathrm{D}$ arrangement along the $c$-axis.

\subsection{Spectroscopic analysis}

Studying the infrared spectra in two sub-regions allows the identification of hydrogen bonding in the solid state: 3550 $3250 \mathrm{~cm}^{-1}$ for N-H stretching vibrations and $1650-1581 \mathrm{~cm}^{-1}$ for $\mathrm{N}-\mathrm{H}$ deformation vibrations $[17,26]$. It has been reported that when hydrogen bonding $(\mathrm{X}-\mathrm{H} \cdots \mathrm{Y})$ occurs in solid state, the $\mathrm{X}-\mathrm{H}$ stretching vibrations decrease in frequency and conversely the X-H deformation vibrations shift to higher frequencies [27]. Additionally, hydrogen bonding can be associated with the broadening and enhance of intensity of X-H stretching vibrations [27]. Thus, in order to provide further evidence for the possible presence of motif II, we analyzed comparatively these regions and vibrational bands in the IR spectra of $\mathbf{1}$ and $\mathbf{2}$ (Fig. 4, Table 3).

$\mathrm{N}-\mathrm{H}$ stretching vibrations, although special attention was placed in the bands at $3368 \mathrm{~cm}^{-1} \mathrm{~N}-\mathrm{H}$ stretching, $3292 \mathrm{~cm}^{-1}$ asymmetric N-H stretching and $3149 \mathrm{~cm}^{-1}$ symmetric N-H

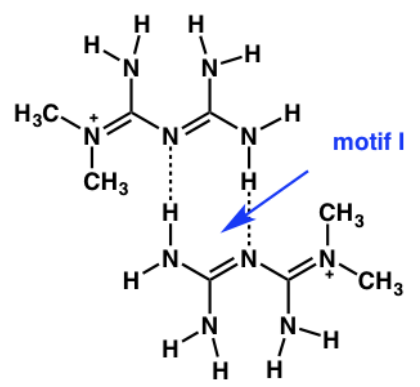

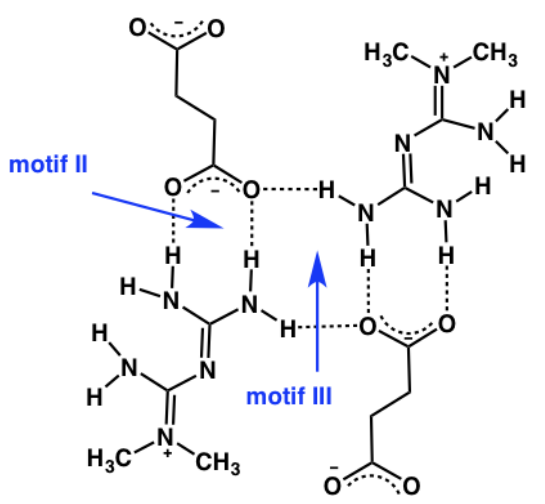

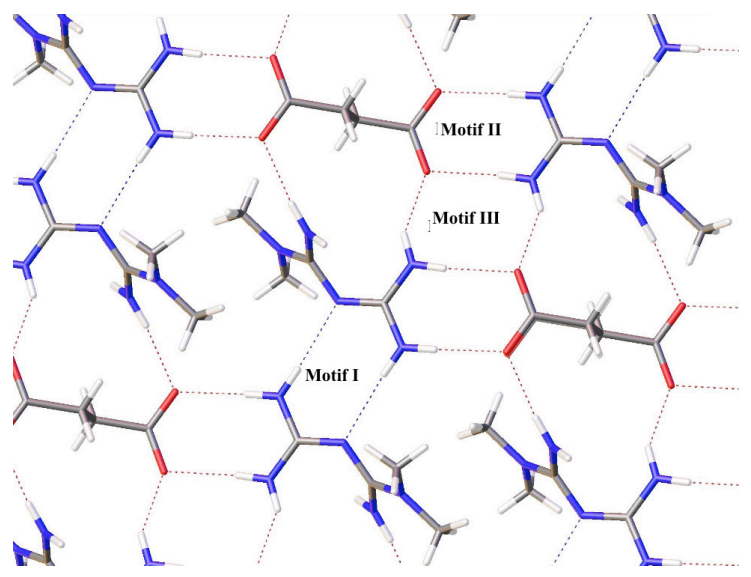

Fig. 3. Hydrogen bonding interactions in crystal structure of 2 .<smiles></smiles>

(a)

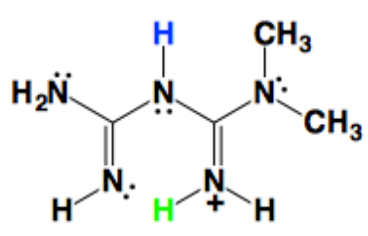

(b)<smiles>C[N+](C)=C(/N=C(\[NH])N)[NH+]=[NH2+]</smiles>

(c)

Scheme 2. Tautomers of H-MET ${ }^{+}$ 
Table 2. Geometric parameters for selected hydrogen bonds of 2.

\begin{tabular}{ccccccc}
\hline Interaction & Motif & D-H $[\AA]$ & H---A $[\AA]$ & D---A $[\AA]$ & D-H-A $\left[{ }^{\circ}\right]$ & $\begin{array}{c}\text { Symmetry } \\
\text { code }\end{array}$ \\
\hline N1-H1A $\cdots$ O2 & III $^{\mathrm{a}}$ & $0.895(9)$ & $2.044(12)$ & $2.8408(16)$ & $147.6(14)$ & $1-\mathrm{X}, 1-\mathrm{Y},-\mathrm{Z}$ \\
$\mathrm{N} 1-\mathrm{H} 1 \mathrm{~B} \cdots \mathrm{O} 2$ & III $^{\mathrm{a}}$ & $0.892(9)$ & $2.028(10)$ & $2.9087(16)$ & $169.0(15)$ & $1+\mathrm{X},+\mathrm{Y},+\mathrm{Z}$ \\
$\mathrm{N} 3-\mathrm{H} 3 \mathrm{~N} \cdots \mathrm{N} 2$ & $\mathrm{I}^{\mathrm{b}}$ & $0.887(9)$ & $2.204(10)$ & $3.0893(17)$ & $176.0(16)$ & $2-\mathrm{X}, 1-\mathrm{Y}, 1-$ \\
$\mathrm{N} 3-\mathrm{H} 3 \mathrm{~B} \cdots \mathrm{O} 1$ & II $^{\mathrm{b}}$ & $0.897(9)$ & $2.051(9)$ & $2.9476(16)$ & $176.9(16)$ & $1+\mathrm{X},+\mathrm{Y},+\mathrm{Z}$ \\
N4-H4A $\cdots \mathrm{O} 1$ & - & $0.899(9)$ & $2.002(10)$ & $2.8969(15)$ & $173.5(15)$ & $1+\mathrm{X}, 1+\mathrm{Y},+\mathrm{Z}$ \\
N4-H4B $\cdots \mathrm{O} 1$ & - & $0.896(9)$ & $2.154(10)$ & $3.0403(15)$ & $170.0(15)$ & $3 / 2-\mathrm{X}, 1 / 2+\mathrm{Y}, 1 / 2-\mathrm{Z}$ \\
\hline
\end{tabular}

a Tetramer $\mathrm{R}_{4}^{2}(8)$ and ${ }^{\mathrm{b}}$ Dimer $\mathrm{R}_{2}^{2}(8)$.

stretching of 1 (Table 3) [26], a straightforward comparison with 2 was not possible due to the broadness of the bands found. In the case of the $\mathrm{N}-\mathrm{H}$ deformation vibrations, for $\mathbf{2}$ they shift to higher frequencies (Table 4) compared with those of $\mathbf{1}$ at 1623 and $1555 \mathrm{~cm}^{-1}$ [26]. This information, in combination with the band at $1650 \mathrm{~cm}^{-1}$ due to large proton polarizability and that due to the unbound $-\mathrm{COO}^{-}$at $1595 \mathrm{~cm}^{-1}$ [28], may suggest the predominant presence of hydrogen bonding (motif II) in 2 (Table 3).

\subsection{Powder X-Ray difraction (PXRD)}

The collection of the PXRD measurements of $\mathbf{1 - 2}$ is shown in Fig. $5, \mathrm{Na}_{2}[\mathrm{SUC}]$ and simulated of $\mathbf{2}$. The experimental and simulated PXRD measurements of $\mathbf{2}$ are practically identical, and different when compared to $\mathbf{1}$ and $\mathrm{Na}_{2}[\mathrm{SUC}]$ salt.

\section{5 ssCPMAS ${ }^{13} \mathrm{C}$ NMR analysis}

The ssCPMAS ${ }^{13} \mathrm{C}$ NMR spectra of $\mathbf{1}, \mathbf{2}$ and $\mathrm{Na}_{2}[\mathrm{SUC}]$ were determined (Fig. 6, see Scheme 3 for the atom numbering of structure). The spectrum of 1 shows three signals, at $\delta 38.5$, 40.5 and a broad one at $\delta 157.6$ and $160.9 \mathrm{ppm}$. The up field signals ( $\delta 38.5$ and $40.5 \mathrm{ppm})$ correlate well with the solution NMR data $\left(\delta 38.4 \mathrm{ppm} \text { in } \mathrm{D}_{2} \mathrm{O}\right)^{17}$. The appearance of the two signals in the solid-state experiment allow to distinguish

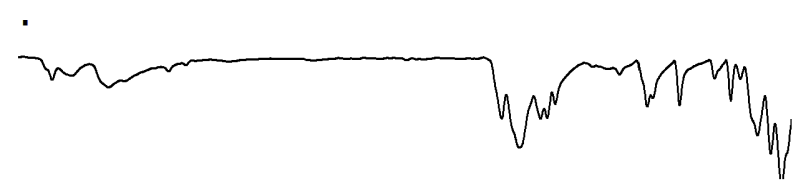

2

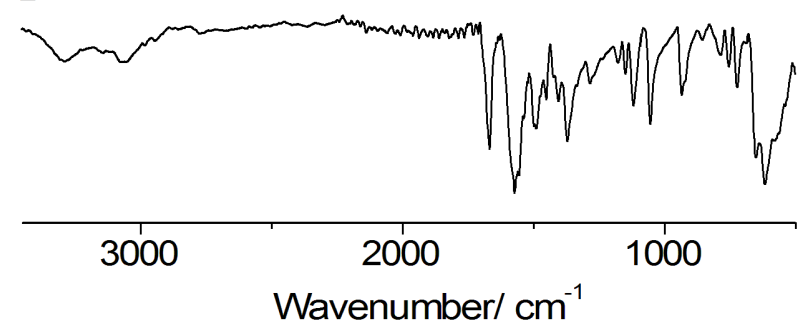

Fig. 4. Infrared spectra of 1 and 2.

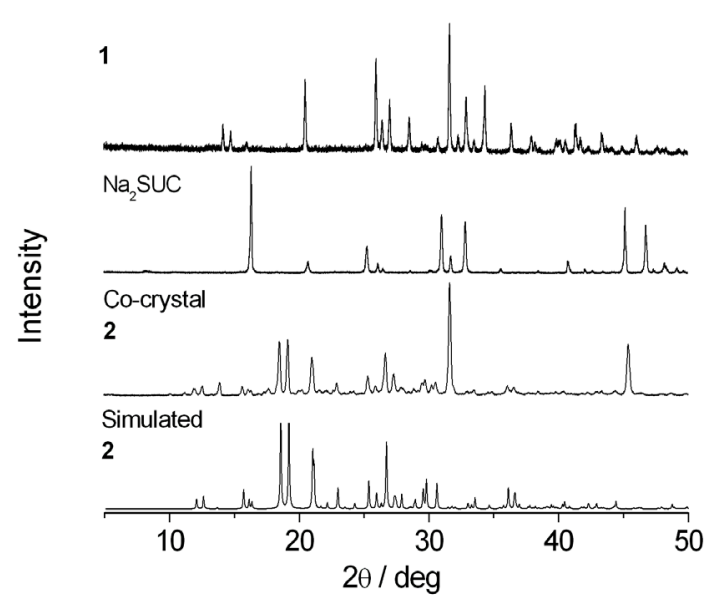

Fig. 5. X-Ray powder diffractions of starting salts (1 and $\left.\mathrm{Na}_{2}[\mathrm{SUC}]\right)$ and experimental and simulated diffraction of product $\mathbf{2}$.

two different $-\mathrm{CH}_{3}$ groups. This observation agrees well with the results observed in the X-ray crystal structure of Metformin hydrochloride [CSD refcode JAMRIY01, polymorph $\mathrm{A}^{20}$ ], where one methyl group has the interaction $\mathrm{C} 3-\mathrm{H} 11 \cdots \mathrm{Cl} 1$ [2.897(16) $\AA$ and $\left.159.53^{\circ}\right]$ while the other shows short contacts C4-H8 $\cdots \mathrm{C} 1$ [2.764(17) $\AA$ and $\left.143.95^{\circ}\right]$. The broad downfield signal corresponds to the quaternary carbons: $\mathrm{C} 2(\delta 160.9 \mathrm{ppm})$ and $\mathrm{C} 3(\delta 157.6 \mathrm{ppm})$.

Table 3. Vibrational band assignment for (1-2).

\begin{tabular}{lll}
\hline Salt & 1 & 2 \\
Frecuency $\left(\mathrm{cm}^{-1}\right)$ & $3368^{\mathrm{a}}$ & not defined \\
$3292^{\mathrm{b}}$ & $3292^{\mathrm{b}}$ \\
$3149^{\mathrm{c}}$ & not defined \\
$1623^{\mathrm{d}}$ & $1665^{\mathrm{d}}(43)^{*}$ \\
& $1555^{\mathrm{e}}$ & $1561^{\mathrm{e}}(6)^{*}$ \\
\hline
\end{tabular}

Vibrational modes: ${ }^{\mathrm{a}} \mathrm{N}-\mathrm{H}$ stretching, ${ }^{\mathrm{b}}$ asymmetric $\mathrm{N}-\mathrm{H}$ stretching, ${ }^{\mathrm{c}}$ symmetric N-H stretching, ${ }^{\mathrm{d}, \mathrm{e}} \mathrm{N}-\mathrm{H}$ deformation. ${ }^{*}$ In parentheses is the absolute value of shifting, $\left|\Delta \mathrm{cm}^{-1}\right|=$ vibration mode of $\mathbf{1}$ vibration mode of 2 . 




H-MET+

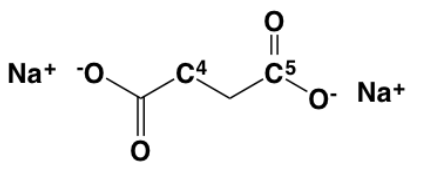

$\mathrm{Na}_{2}[\mathrm{SUC}]$

Scheme 3. Numbering of carbon atoms of $\mathbf{1}$ and $\mathrm{Na}_{2}[\mathrm{SUC}]$ for the assignation of chemical shifts.

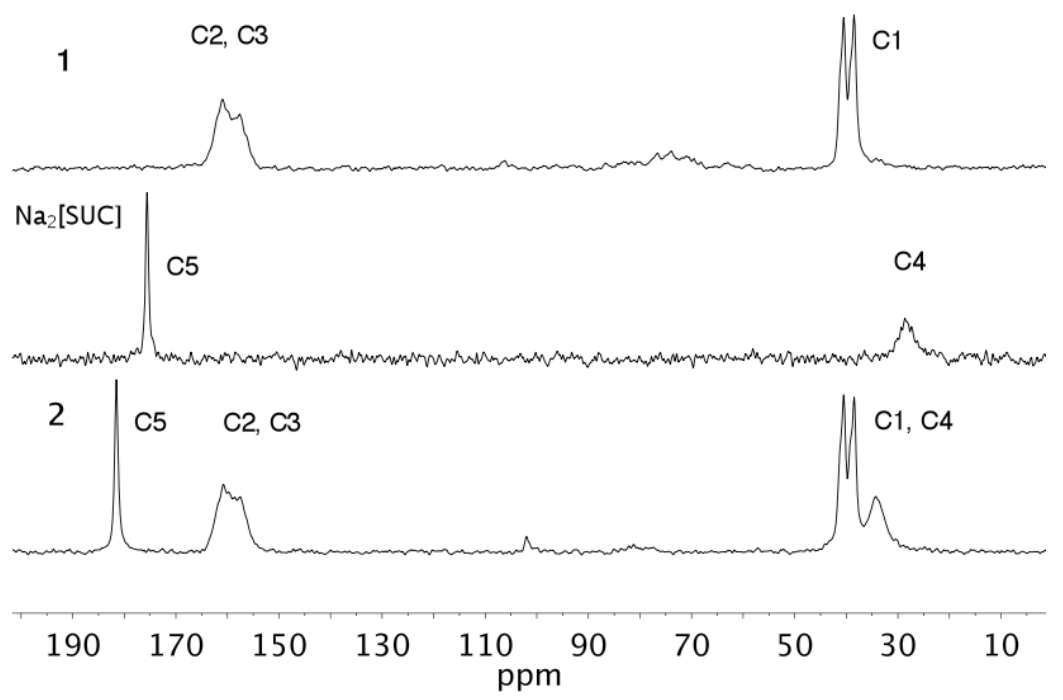

Fig. 6. ssCPMAS ${ }^{13} \mathrm{C}$ NMR spectra of $\mathbf{1}, \mathrm{Na} 2[\mathrm{SUC}]$ and 2.

For the case of $\mathrm{Na}_{2}[\mathrm{SUC}]$, assignation of the signals in the CPMAS ${ }^{13} \mathrm{C}$ NMR spectra was straightforward based on comparison with the reported data [29]. The CPMAS ${ }^{13} \mathrm{C}$ spectrum of 2 exhibits five signals, two downfield at $\delta 34.30,38.45$ and 40.47 , which by comparison with the spectra of the precursors, the signal at $\delta 34.30 \mathrm{ppm}$ corresponds to $\mathrm{C} 4$ of succinate anion and the other two intense signals are due to $\mathrm{C} 1$. According with the X-ray structure of 2, two distinguishable $-\mathrm{CH}_{3}$ are noted due to short contact C6-H6A $\cdots \mathrm{O} 1\left[2.702 \AA\right.$ and $\left.114.10^{\circ}\right]$ and $\mathrm{C} 5-\mathrm{H} 5 \mathrm{~B} \cdots \mathrm{N} 1\left[2.736 \AA\right.$ and $\left.154.82^{\circ}\right]$. In addition, at up field two more signals are observed; the broad one, again, composed of two overlapped signals due to $\mathrm{C} 2$ and $\mathrm{C} 3$. Whilst the signal at $\delta 181.5 \mathrm{ppm}$ is due to $\mathrm{C} 5$ of the succinate anion. No significant $\Delta \delta(-0.07 \mathrm{ppm})$ is observed in this signal compared with $\mathrm{Na}_{2}[\mathrm{SUC}]$ (Table 4).

\subsection{Dissolution rates profiles}

In order to explore the potential of $\mathbf{2}$, for comparative purposes, we determined the intrinsic dissolution rate constants of $\mathbf{2}$ and 1 under physiological conditions. The experiments were performed using tablets of $\mathbf{1}$ and $\mathbf{2}$ (crushed single crystals were employed), prepared with a hydraulic press at a total force of $220 \mathrm{~kg} / \mathrm{cm}^{2}$. The dissolution rates were determined with a Wood's apparatus with phosphate buffer at $\mathrm{pH}$ 6.8. Experiments were carried out by triplicated at $37^{\circ} \mathrm{C}$ under constant stirring $(50 \mathrm{rpm})$ in a constant volume of $900 \mathrm{~mL}$. Determinations were done using a UV-vis spectrometer (Thermo Scientific Evolution 60) monitoring the absorption band at $233 \mathrm{~nm}$ using a validated method for $\mathrm{MET} \cdot \mathrm{HCl}$ [30], permitting quantify the amount of drug dissolved in a giving period of time to establish the dissolution rate profile.

The comparison of intrinsic dissolution profiles of $\mathbf{1}$ and $\mathbf{2}$ is shown in Fig. 7. One can easily observe that $\mathbf{1}\left(\mathrm{K}_{\mathrm{int}}=2.94\right.$ $\mathrm{mg} / \mathrm{min}^{*} \mathrm{~cm}^{2}$ ) shows an initial rapid dissolution and minimal variations of this behavior during the period of time of the determinations, conversely for $\mathbf{2}\left(\mathrm{K}_{\mathrm{int}}=0.885 \mathrm{mg} / \mathrm{min}^{*} \mathrm{~cm}^{2}\right)$ the dissolution rate increases constantly, allowing us to conclude that indeed $\mathbf{2}$ exhibits a sustained-release drug delivery behavior compared with $\mathbf{1}$. This behavior can be attributed to the markedly difference between the values of hydration energy of chloride anion $\left(\Delta \mathrm{G}^{\circ}=-340 \mathrm{~kJ} \mathrm{~mol}^{-1}\right)[30]$ and succinate $\left(\Delta \mathrm{G}^{\circ}\right.$ $\left.=-118 \mathrm{~kJ} \mathrm{~mol}^{-1}\right)$ [31]. 
Table 4. CPMAS ${ }^{13} \mathrm{C}$ NMR chemical shifts of $\mathbf{1}, \mathrm{Na}_{2}[\mathrm{SUC}]$ and 2.



Differences in the chemical shifts $\Delta$ CPMAS ${ }^{13} \mathrm{C}=\left(\delta \mathbf{2}-\delta \mathbf{1}\right.$ or $\left.\mathrm{Na}_{2}[\mathrm{SUC}]\right)$. Chemicals shifts are given in ppm.

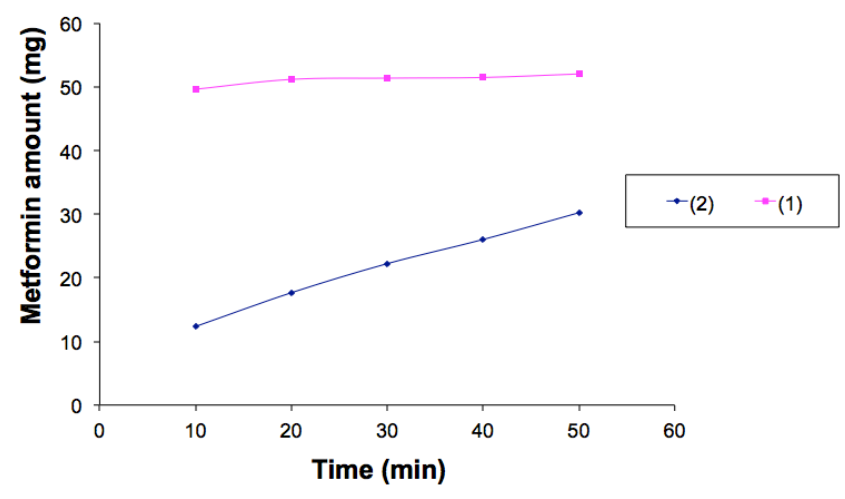

Fig. 7. Intrinsic dissolution profiles of $\mathbf{1}$ and $\mathbf{2}$.

\section{Conclusions}

The melting reaction of $\mathrm{MET} \cdot \mathrm{HCl}$ with dehydrated sodium succinate at $220^{\circ} \mathrm{C}$ can be used as a rapid $(10 \mathrm{~min})$ and efficient method to produce $[\mathrm{MET}]_{2}[\mathrm{SUC}] \mathbf{2}$. The crystal structure of $\mathbf{2}$ is described for first time, this salt displays a 2:1 stoichiometric ratio where metforminiun $\mathrm{H}_{-} \mathrm{MET}^{+}$and succinate ions are linked via charged-assisted hydrogen bonds of type $\mathrm{N}-\mathrm{H}^{\cdots} \mathrm{O}^{-}$ (carboxylate), this interactions extending into a 2D network. Solid state CPMAS ${ }^{13} \mathrm{C}$ NMR experiments support the formation of the new solid phase of $\mathbf{2}$. The salt $\mathbf{2}$ exhibits a sustained-release behavior in water under physiological conditions as compared to the commercial $\mathrm{MET} \cdot \mathrm{HCl}$ 1. The simplicity of the method reported in this work opens new opportunities for the synthesis of a new series of derivative salts of metformin. In terms of practical application, this report provides a method that avoids the use of solvents, one of the mayor problems in the pharmaceutical industry, thus potentially greening the production of 2 . Although, with some caveats, being in this case the production of $\mathrm{NaCl}$ an unwanted by-product particularly when refers to T2DM treatment. However, one can envisage this problem to be easily solved by washing the final product with ethanol [33].

\section{Supplementary information}

Crystallographic data for salt $\mathbf{2}$ have been deposited at the Cambridge Crystallographic Data Centre. Copies of this information are available free of charge on request from The Director, CCDC, 12 Union Road, Cambridge, CB2 1EZ, UK (Fax: +44-1223-336033; e-mail deposit@ccdc.cam.ac.uk or www: http://www.ccdc.cam.ac.uk) CCDC 1053449.

\section{Acknowledgements}

We would like to thank M.Sc. Lizbeth Triana Cruz, M.Sc. Ma. De las Nieves Zavala Segovia, M.Sc. Alejandra Núñez Pineda, M.Sc. Adriana Tejeda Cruz, Ch.E. Eriseth Reyes Morales, Dr. Diego Martínez-Otero and Powder X-ray Diffraction Laboratory CCIQS-UNAM (Uvaldo Hernández B.). The financial support of this research by CONACYT (PDCPN247089 and CB239648) and DGAPA-UNAM (PAPIIT-IA202315) is gratefully acknowledged. The authors would like to thank, programa de muestras externas no remuneradas para su análisis del CCIQS, for the Project DMM-2016-1 “Diseño y caracterización de cocristales/sales/cocristales iónicos fármaco:fármaco para el potencial tratamiento de la diabetes tipo 2 y sus factores de riesgo asociados".

\section{References}

1. (a) Vishweshwar, P.; McMahon, J. A.; Zaworotko, M. J. Frontiers in Crystal Engineering, John Wiley \& Sons Ltd, Chichester, 2006. (b) Peterson, M. L., Collier, E. A., Hickey, M. B., Guzman, H., Almarsson, Ö. Organic Crystal Engineering, John Wiley \& Sons Ltd, Chichester, 2010. (c) Vishweshwar, P.; McMahon, J. A.; Bis, J. A.; Zaworotko, M. J. J. Pharm. Sci. 2006, 95, 499-516. (d) Shan, N.; Zaworotko, M. J. Drug Discov. Today. 2008, 13, 440-446. (e) Meanwell, N. A. Annu. Rep. Med. Chem. 2008, 43, 373-404. (f) Friščić, T.; Jones, W. J. Pharm. Pharmacol. 2010, 62, 15471559. (g) Qiao, N.; Li, M.; Schlindwein, W.; Malek, N.; Davies, A.; Trappitt, G. Int. J. Pharm. 2011, 419, 1-11. (h) Desiraju, G. R.; 
Vittal, J. J.; Ramanan, A. Crystal Engineering: A Textbook, World Scientific Publishing 2011. (i) Brittain, H. G. Cryst. Growth Des. 2012, 12, 1046-1054. (j) Patel, P. V.; Brahmbhatt, H.; Upadhyay, U. M.; Shah, V. Int. J. Pharm. Sci. Rev. Res. 2012, 16, 140-148 (k) Steed, J. W. Trends Pharm. Sci. 2013, 34, 185-193. (1) Blagden, N.; Coles, S. J.; Berry, D. J. CrystEngComm. 2014, 16, 57535761. (m) Aakeröy, C. B.; Forbes, S.; Desper, J. CrystEngComm. 2014, 16, 5870-5877.

2. Bristol-Myers (2002) Glucophage ${ }^{\circledR}$ Metformin Hydrochloride Product Information. Merck Santé S.A.S and associate of Merck. Darmstadt, Germany.

3. Coughlan, K. A.; Valentine, R. A.; Ruderman, N. B.; Saha, A. K. Diabetes Metab. Syndr. Obes. 2014, 7, 241-253.

4. Akhtar, M. S.; Irshad, N.; Malik, A.; Kamal, Y. Int. J. Pharm. Sci. Res. 2013, 4, 77-82.

5. Evans, J. M.; Donelly, L. A.; Emslie-Smith, A. M.; Alessi, D. R.; Morris, A. D. Brit. Med. J. 2005, 330, 1304-1305.

6. (a) Ochoa-Lara, J. M. F. International Patent WO2012148252 A2, 2012. (b) German-Acacio, J. M., Morales-Morales, D. Organic \& Medicinal Chem. I. J. 2017; 1(4): 555569. DOI: 10.19080/OMCIJ.2017.01.555569.

7. (a) Lu, E.; Rodríguez-Hornedo, N.; Suryanarayanan, R. CrystEngComm. 2008, 10, 665-668. (b) Fucke, K.; Myz, S. A.; Shakhtshneider, T. P.; Boldyreva, E. V.; Griesser, U. J. New J. Chem. 2012, 36, 1969-1977. (c) Manin, A. N.; Voronin, A. P.; Drozd, K. V.; Manin, N. G.; Bauer-Brandl, A.; Perlovich, G. L. Eur. J. Pharm. Sci. 2014, 65, 56-64. (d) Sarceviča, I.; Kons, A.; Orola, L. CrystEngComm. 2016, 18, 1625-1635. (e) Nayak, A.; Pedireddi, V. R. Cryst. Growth Des. 2016, 16, 5966-5975

8. Nanubolu, J. B.; Sridhar, B.; Ravikumar, K.; Sawant, K. D.; Naik, T. A.; Patkar, L. N.; Cherukuvadac, S.; Sreedhar, B. CrystEngComm. 2013, 15, 4448-4464. And references therein cited.

9. Allen, F. H. Acta Crystallogr., Sect. B: Structural Science. 2002, 58, 380-388.

10. Pérez-Fernández, R.; Fresno, N.; Goya, P.; Elguero, J.; Menéndez-Taboada, L.; García-Granda, S.; Marco, C. Cryst. Growth Des. 2013, 13, 1780-1785.

11. Dwichandra Putra, O.; Furuishi, T.; Yonemochi, E.; Terada, K.; Uekusa, H. Cryst. Growth Des. 2016, 16, 3577-3581.

12. (a) Timmins, P.; Winter, W. J.; Srivastava, S. K.; Bretnall, A. E.; Powers, G. L. US patent, US 006031004 A, 2000. (b) Kolesova, O. E.; Georgievic Nenajdenko, V.; Anatolievich Pomytkin, I.; Jurievna Ulkhanova, T.; Vasilievich Verteletsky, P. International Patent, WO2002012177 A1, 2002. (c) Sung Wuk, K.; Sung Soo, J.; Young Gwan, J.; Ja Seong, K.; Young Woong, K.; Byoung Ha, K.; Duk, K. International Patent WO 2009/038396 A2, 2009. (d) Timmins, P.;Winter, W. J.; K. Srivastava, S.; Bretnall, A.; Wei, C.; Powers, G. International Patent, WO 9929314 A1, 1999. (e) Seong Uk, K.; Seong Su, J.; Yeong Gwan, C.; Ja Seong, K.; Yeong Ung,
K. International Patent, WO 2008/093984 A1, 2008. (f) Mylari, B. L.; Sciavolino, F. C. US patent US 2014/0249221 A1, 2014. (g) Mylari, B. L. International Patent WO 2009/085198 A2, 2009. (h) Lara Ochoa, J. M. F. International Patent WO 2009144527 A1, 2009. (i) Yeon Won, G.; Uk Kim, D.; Eon Pyo Kang H.; Seok, H. Korean patent KR 2011123881 A, 2011.

13. Barbour, J. L. J. Supramol. Chem. 2001, 1, 189-191.

14. Dolomanov, O. D.; Bourhis, L. J.; Gildea, R. J.; Howard, J. A. K.; Puschmann H. J. Appl. Cryst. 2009, 42, 339-341.

15. Blessing, R. H. Acta Crystallogr., Sect. A: Found. Crystallogr. 1995, 51, 33-38.

16. Sheldrick, G. M. SHELX TL, University of Göttingen, Göttingen, Germany, 1997.

17. Bretnall, A. E.; Clarke, G. S. Anal. Profiles Drug Subst. Excipients. 1998, 25, 243-293.

18. Gál, S.; Meisel, T.; Erdey, L. J. Therm. Anal. 1969, 1, 159-170.

19. Huheey, J. E.; Keiter, E. A.; Keiter, R. L. Inorganic Chemistry. Harper Collins, 1993,

20. Childs, S. L.; Chyall, L. J.; Dunlap, J. T.; Coates, D. A.; Stahly, B. C.; Stahly, G. P. Cryst. Growth Des. 2004, 4, 441-449.

21. (a) Etter, M. C.; MacDonald, J. C.; Bernstein, J. Acta Crystallogr., Sect. B: Structural Science. 1990, 46, 256-262; (b) Bernstein, J.; Davies, R. E.; Shimoni, L.; Shang, N. L. Angew. Chem. Int. Ed. Engl. 1995, 34, 1555-1573.

22. Murugavel, S.; Kannan, P. S.; Subbiah Pandi, A.; Govindarajand, S.; Selvakumar, R. Acta Crystallogr., Sect. E: Structure Reports Online. 2009, 65, o454.

23. Matulková, I.; Němec, I.; Císařová, I.; Němec, P.; Vanek, P. J. Mol. Struct. 2010, 966, 23-32.

24. Videnova-Adrabinska, V.; Obara, E; Lis, T. New J. Chem. 2007, 31, 287-295.

25. Matulková, I.; Císařová, I. and Němec, I. Acta Crystallogr., Sect. E: Structure Reports Online. 2010, 66, o3187-o3188.

26. Sheela, N. R.; Muthu, S. and Sampath-Krishnan, S. Asian J. Chem. 2010, 22, 5049-5056.

27. Turrell, G. Infrared and Raman Spectra of Crystals, Academic Press Inc. 1972.

28. (a) Brzezinski, B.; Olejnik, J. and Zundel, G. J. Chem. Soc. Faraday Trans. 1994, 40, 1095-1098. (b) Kamino, A.; Koyano, H.; Ariga, K. and Kunitake, T. Bull. Chem. Soc. Jpn. 1996, 69, 3619-3631.

29. Schröter, B.; Rosenberger, H.; Hadži, D. J. Mol. Struct. 1983, 96, 301-314.

30. ICH Q2 (r1) Farmacopea de los Estados Unidos de México $11^{\text {th }}$ Edition.

31. Butler, S. J.; Parker, D. Chem. Soc. Rev. 2013, 42, 1652-1666.

32. Kambalapalli, S.; Ortiz, J. V. J. Phys. Chem. A. 2003, 107, 1036010369

33. Pinho, S. P., Macedo, E. A. J. Chem. Eng. Data 2005, 50, 29-32. 